\title{
Preparation of New $\pi$-Conjugated Thiophene-Pyrrole Copolymers Having Ethynyl Substituents at the $N$-Position of Pyrrole
}

\author{
By Takakazu YAMAмото* and Risako YAMASHITA
}

KEY WORDS: Copolymers / Thiophene / Pyrrole / UV-visible Spectra / Electrochemical Response /

$\pi$-Conjugated polymers are the subject of many papers. ${ }^{1}$ Polythiophenes and polypyrroles are centrally important $\pi$ conjugated polymers, and some of them have been adopted in industry. ${ }^{2,3}$

Copolymers of thiophene and pyrrole have also been reported. ${ }^{4,5}$ The copolymers have usually been prepared by oxidative polymerization of the monomers. However, characterization of the copolymers prepared by the oxidative polymerization and revealing their chemical properties have not been explored much. We now report synthesis of three alternating copolymers of thiophene and pyrrole via organometallic polycondensation and chemical properties of the synthesized copolymers.

As the pyrrole unit, we are recently concerned with that having an acetylenic $-\mathrm{C} \equiv \mathrm{CR}$ side chain at the $N$-position, ${ }^{5}$ and the copolymers reported in this paper also have acetylenic $-\mathrm{C} \equiv \mathrm{CR}$ side chains at the $N$-position. The $-\mathrm{C} \equiv \mathrm{CR}$ side chain has a $\pi$-electron system which is expected to have an electronic interaction with the $\pi$-conjugated system of the polypyrrole main chain, and $\pi$-conjugated polymers having such electronic interaction between the main chain and the side chain has attracted interaction of polymer chemists. ${ }^{6}$

Non-substituted pyrrole has high chemical reactivity, ${ }^{7}$ and non-substituted polypyrrole undergoes various oxidation and reduction reactions participated by hydrogen(s) in the pyrrole unit. ${ }^{7 \mathrm{~d}}$ Consequently enough characterization of $\pi$-conjugated polymers constituted of the non-substituted pyrrole unit is sometimes difficult. ${ }^{7 d}$ However, the pyrrole unit with the $-\mathrm{C} \equiv \mathrm{CR}$ side chain at the $\mathrm{N}$-position is chemically stable even when it is in a $\pi$-conjugated polymer system. ${ }^{5} \pi$-Conjugated polymers with acetylenic $-\mathrm{C} \equiv \mathrm{CR}$ side chains are the subject of recent interest. ${ }^{8}$

\section{RESULTS AND DISCUSSION}

The following alternating copolymers, P1, P2, and P3, were synthesized according to Pd-catalyzed Stille type polycondensation between the bis(trimethylstannyl) monomer and dibromo monomer, as shown in Scheme 1. P1 and P2 were partly (about 1/3) soluble in DMF, and P3 was soluble in organic solvents such as chloroform, DMF, and THF. GPC (gel permeation chromatography) of the DMF-soluble parts of $\mathbf{P 1}$ and $\mathbf{P 2}$ showed number average molecular weight $\left(M_{\mathrm{n}}\right.$ 's) of 4800 and 4000 with $M_{\mathrm{w}} / M_{\mathrm{n}}$ values $\left(M_{\mathrm{w}}=\right.$ weight average molecular weight) of 2.0 and 2.4 , respectively. $\mathbf{P 3}$ showed $M_{\mathrm{n}}$ and $M_{\mathrm{w}}$ of 2600 and 4160, respectively. Although the $M_{\mathrm{n}}$ and $M_{\mathrm{w}}$ values of P1-P3 were not large, the polymers are considered to show basic chemical properties of such thiophene-pyrrole copolymers. P3 has a large $\pi$-conjugated side chain which is expected to communicate electronically with the main chain. ${ }^{6}$ However, synthesis of $\pi$-conjugated polymers with such a large $\pi$-conjugated side chain has no precedent to our knowledge. Revealing electronic and optical properties of polymers with such a large $\pi$-conjugated side chain might expand chemistry of $\pi$-conjugated polymers.

The IR spectra of P1-P3 were reasonable for the molecular structure, and showed a $v(\mathrm{C} \equiv \mathrm{C})$ peak at about $2250 \mathrm{~cm}^{-1}$. Figure 1 shows ${ }^{1} \mathrm{H}$ NMR spectrum of $\mathbf{P 2}$. The $-\mathrm{CH}_{3}$ signal of the tolyl group and the pyrrole-H signal appear at $\delta 2.40$ and 6.82 , respectively.

The peak area ratio between the $\mathrm{CH}_{3}$ signal and the aromatic signals agrees with the molecular structure of P2. The peak area ratio between the aliphatic signals and aromatic signals in the ${ }^{1} \mathrm{H}$ NMR spectrum of $\mathbf{P 3}$ also agrees with the molecular structure of P3. P1 gave rise to only the aromatic-H signals in the ${ }^{1} \mathrm{H}$ NMR spectrum, and its characterization was made mainly based on data from elemental analysis, IR, and GPC. $\mathrm{CP} / \mathrm{MAS}$ solid- ${ }^{13} \mathrm{C}$ NMR spectra of the polymers showed acetylenic $\mathrm{C}$ signals at about $\delta 83$ and 74. Powder X-ray diffraction (XRD) patterns of $\mathbf{P 1}$ and $\mathbf{P 2}$ showed some peaks (e.g., at $d=4.8$ and $3.8 \AA$ for $\mathbf{P 1}$ and $d=13.3,4.5$, and $3.9 \AA$ for $\mathbf{P 2}$, respectively). An assumption of a laterally facecentered type packing of P2, similar to that of poly(3methylthiophene), ${ }^{9}$ gave a calculated density of $1.33 \mathrm{~g} \mathrm{~cm}^{-3}$, which agreed with an observed density of $1.34 \mathrm{~g} \mathrm{~cm}^{-3}$ in the experimental error. The XRD pattern of $\mathbf{P 3}$ showed only a broad peak at $d=4.2 \AA$ which is considered to correspond to loose packing ${ }^{10}$ of the hexyl groups in the side chain.

Figure 2 shows UV-vis spectrum of $\mathbf{P 1}$ in DMF and cast film.

As shown in Figure 2, the UV-vis peak of P1 appears at $469 \mathrm{~nm}$ in DMF. $\mathbf{P 2}$ and $\mathbf{P 3}$ show the UV-vis peaks at $435 \mathrm{~nm}$ 
<smiles>CSc1ccc(-c2ccc(S(C)(C)C)s2)s1</smiles>

1a: $R=-H$
1b: $R=-\mathrm{CH}_{3}$

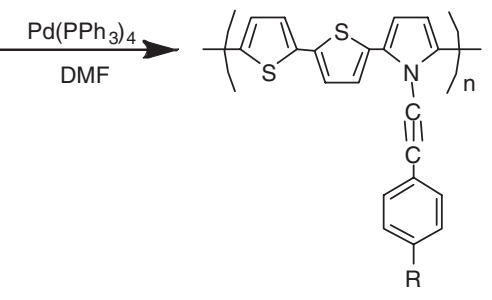

P1: $\mathrm{R}=-\mathrm{H}^{-}$

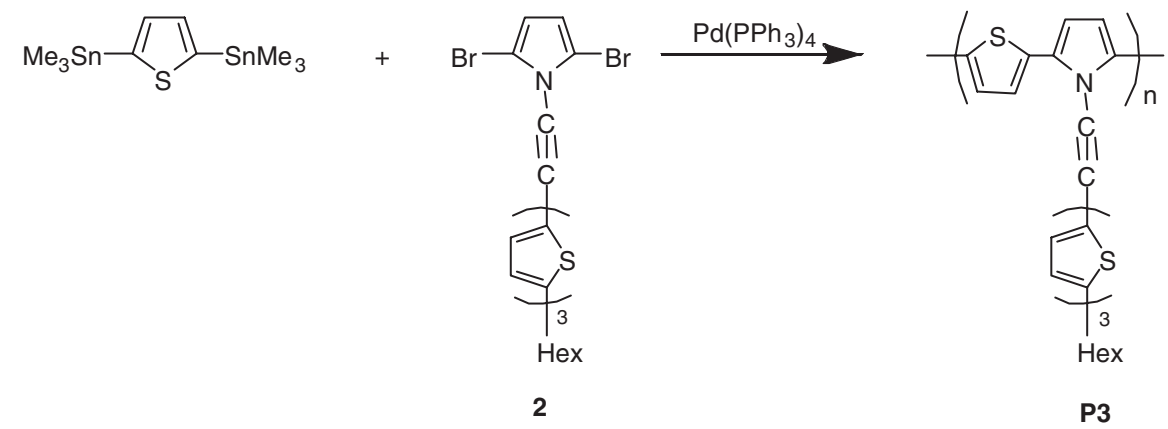

Scheme 1. Synthesis of the thiophene-pyrrole copolymers.

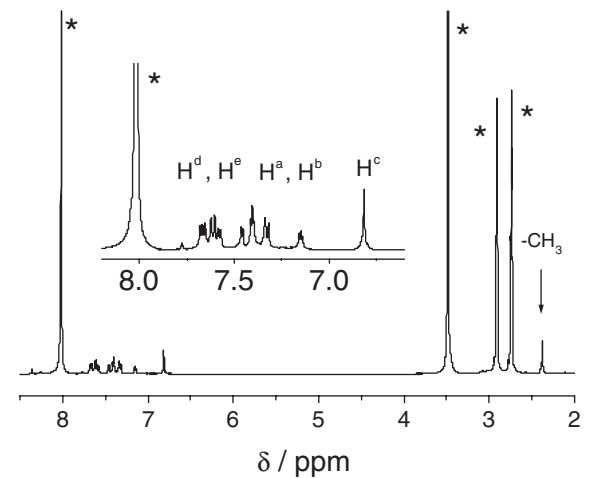

Figure 1. ${ }^{1} \mathrm{H}$ NMR spectrum of $\mathbf{P 2}$ in DMF- $d_{7}$. Peaks with $*$ are due to solvent impurities (DMF- $d_{6}$ 's and $\mathrm{H}_{2} \mathrm{O}$ ). The signal at $\delta 6.82\left(\mathrm{H}^{\mathrm{c}}\right)$ is assigned to pyrrole-H. Other aromatic signals $\left(\mathrm{H}^{\mathrm{a}}, \mathrm{H}^{\mathrm{b}}, \mathrm{H}^{\mathrm{d}}\right.$, and $\left.\mathrm{H}^{\mathrm{e}}\right)$ appear in the range of $\delta 7.15-7.8$.

and $410 \mathrm{~nm}$, respectively, in DMF. The $\lambda_{\max }$ values of P1-P3 are comparable to those ( $\mathrm{ca}$. $400-440 \mathrm{~nm}$ ) of reported copolymers of pyrrole, thiophene, and 3-dodecylthiophene, ${ }^{4 \mathrm{~b}}$ which have been prepared by oxidative polymerization of the mixed monomers and reduced (or neutralized) by treatment with hydrazine. The $\lambda_{\max }$ values are also comparable to those of polythiophene $\left(\lambda_{\max }=c a .440 \mathrm{~nm}\right)$ and head-to-tail type poly(3-alkylthiophene) $\left(\lambda_{\max }=c a .450 \mathrm{~nm}\right){ }^{1}$ revealing that various $\pi$-conjugated polymers constituted of similar fivemember rings give the UV-vis peak at near positions. The UVvis peaks of P1-P3 show only small shifts between the solution and the cast film (from 469, 435, $410 \mathrm{~nm}$ in solutions to 512 , 452, and $425 \mathrm{~nm}$ in films for $\mathbf{P 1}, \mathbf{P 2}$, and $\mathbf{P 3}$, respectively),

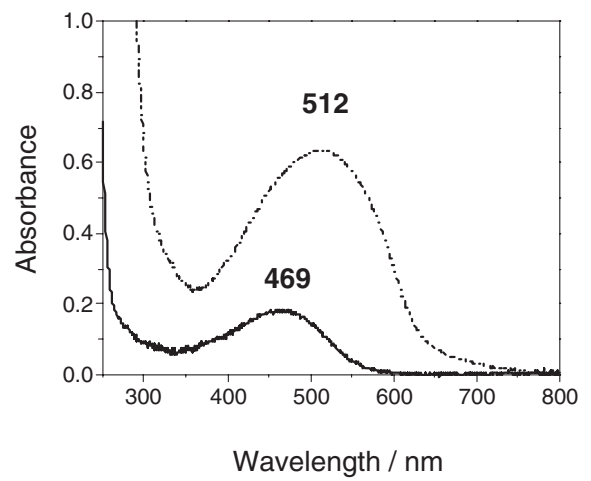

Figure 2. UV-vis spectra of $\mathbf{P} 1$ in DMF (solid line) and cast film on a nonfluorescent glass plate (broken line). The numbers in the figure indicate the wavelength of the peak in $\mathrm{nm}$.

which suggest the absence of a strong electronic interaction between the polymer molecules in the solid. Diffuse reflectance spectra of DMF-insoluble parts of $\mathbf{P 1}$ and $\mathbf{P 2}$ showed their absorption peaks at 462 and $461 \mathrm{~nm}$, respectively.

Electrochemical properties of P1-P3 have been investigated by cyclic voltammetry (CV) using cast films of the polymers. The CV charts showed oxidation (or p-doping) peaks at 0.30, 0.28 , and $0.29 \mathrm{~V} v s$. $\mathrm{Ag}^{+} / \mathrm{Ag}$ for $\mathbf{P 1}, \mathbf{P} 2$, and $\mathbf{P 3}$, respectively. The oxidation peaks located between those of polythiophene (about $0.6 \mathrm{~V}$ vs. $\mathrm{Ag}^{+} / \mathrm{Ag}$ ) and polypyrrole (about $-0.2 \mathrm{~V}$ vs. $\mathrm{Ag}^{+} / \mathrm{Ag}$ ). ${ }^{1}$ Coupled reduction (or p-undoping) peaks of the polymers were broadened, and broad reduction peaks of $\mathbf{P 2}$ and $\mathbf{P 3}$ appeared at about 0.15 and $-0.05 \mathrm{~V}$ vs. $\mathrm{Ag}^{+} / \mathrm{Ag}$, respectively. 
As described above, new thiophene-pyrrole copolymers have been synthesized. The obtained results give additional information about such a type of copolymers constituted of thiophene and pyrrole rings.

\section{EXPERIMENTAL}

Commercially available 5,5'-bis(trimethylstannyl)-2,2'-bithiophene $\left(\mathrm{Me}_{3} \mathrm{Sn}-\mathrm{Th}_{2}-\mathrm{SnMe}_{3}\right)$ and 2,5-bis(trimethylstannyl)thiophene $\left(\mathrm{Me}_{3} \mathrm{Sn}-\mathrm{Th}-\mathrm{SnMe}_{3}\right)$ were used as purchased. The monomer 1a were prepared according to the literature. ${ }^{5}$

IR and UV-vis spectra were recorded on a JASCO FT/IR460plus and a Shimadzu UV-3100PC spectrometers, respectively. UV-vis diffuse reflectance spectra ${ }^{11}$ were measured on a Shimadzu UV-3100PC spectrometer equipped with an integrating sphere assembly and transformed to the UV-vis absorption spectra using Kubelka-Munk theory; $\mathrm{BaSO}_{4}$ was the reference standard. ${ }^{1} \mathrm{H}$ NMR spectra were obtained with JEOL JNM-LA300 and JEOL JNM-EX400 spectrometers. Cyclic voltammetry was carried out using a Hokuto Denko HSV-100 system. The cast film on a glassy carbon electrode, a Pt plate $(1 \times 2 \mathrm{~cm})$, and $\mathrm{Ag}^{+} / \mathrm{Ag}$ were used as the working, counter, and reference electrodes, respectively. The measurement was carried out in a DMF solution of $\left[\mathrm{NBu}_{4}\right] \mathrm{BF}_{4}(0.10 \mathrm{M})$ under $\mathrm{N}_{2}$ at room temperature. Powder and film XRD data were obtained with a RINT 2100Ultima ${ }^{+} / \mathrm{PC}$ diffractometer. GPC was carried out with a TOSOH HLC-8120 liquid chromatograph using DMF containing $\operatorname{LiBr}(0.01 \mathrm{M})$ as the eluent.

The monomers $\mathbf{1 b}$ and $\mathbf{2}$ were prepared according to the methods described below.

Pyrrole (2.46 g, $36.3 \mathrm{mmol})$ and $\mathrm{NaH}(0.88 \mathrm{~g}, 36.6 \mathrm{mmol})$ were added to $50 \mathrm{~mL}$ of dry THF, and the mixture was stirred for $2 \mathrm{~h}$ at $60^{\circ} \mathrm{C}$. After cooled to room temperature, 2- $p$-tolyl-1chloroethyne $^{12}$ (5.00 g, $33.3 \mathrm{mmol}$ ) was added, and the reaction mixture was stirred for $24 \mathrm{~h}$ at $60^{\circ} \mathrm{C}$. After addition of water, the product was extracted with hexane and dried with $\mathrm{Na}_{2} \mathrm{SO}_{4}$. Purification by column chromatography on $\mathrm{SiO}_{2}$ (eluent $=$ hexane) gave 1-(2-p-tolylethynyl)pyrrole as a white solid (3.68 g, $61 \%$ yield). ${ }^{1} \mathrm{H} \mathrm{NMR}\left(\mathrm{CDCl}_{3}\right): \delta 7.36(\mathrm{~d}, 8.4 \mathrm{~Hz}, 2 \mathrm{H}), 7.13$ (d, 8.4 Hz, 2H), $6.92(\mathrm{t}, 2.2 \mathrm{~Hz}, 2 \mathrm{H}), 6.20(\mathrm{t}, 2.2 \mathrm{~Hz}, 2 \mathrm{H}), 2.35$ (s, 3H). Anal: Calcd. for $\mathrm{C}_{13} \mathrm{H}_{11} \mathrm{~N}$ : C, 86.15\%; H, 6.12\%; N, 7.73\%; Found: C, 86.39\%; H, 6.23\%; N, 7.57\%.

$N$-Bromosuccinimide (NBS, $1.65 \mathrm{~g}, 9.28)$ was added to a DMF $(80 \mathrm{~mL})$ solution of 1-(2-p-tolylethynyl)pyrrole $(0.80 \mathrm{~g}$, $4.42 \mathrm{mmol}$ ), and the mixture was stirred at $0{ }^{\circ} \mathrm{C}$ (ice bath). After warmed to room temperature, the reaction mixture was stirred for $16 \mathrm{~h}$. After addition of water, the product was extracted with hexane and dried over $\mathrm{Na}_{2} \mathrm{SO}_{4}$. Purification by column chromatography on $\mathrm{SiO}_{2}$ (eluent $=$ hexane) gave the monomer $\mathbf{1 b}$ as a colorless liquid $\left(1.00 \mathrm{~g}, 66 \%\right.$ yield). ${ }^{1} \mathrm{H}$ NMR $\left(\mathrm{CDCl}_{3}\right): \delta 7.45(\mathrm{~d}, 7.9 \mathrm{~Hz}, 2 \mathrm{H}), 7.16(\mathrm{~d}, 7.9 \mathrm{~Hz}, 2 \mathrm{H}), 6.21(\mathrm{~s}$, $2 \mathrm{H}$ ), 2.37 (s, 3H). Anal: Calcd. for $\mathrm{C}_{13} \mathrm{H}_{9} \mathrm{Br}_{2} \mathrm{~N}$ : C, 46.06\%; $\mathrm{H}$, $2.68 \%$; Br, 47.14\%; N, 4.13\%; Found: C, 46.29\%; H, 2.46\%; $\mathrm{Br}, 47.30 \%$; N, $4.20 \%$.

Reaction of 1 -( $5^{\prime \prime}$-hexyl)-2 $2^{\prime \prime}, 2^{\prime} ; 5^{\prime}, 2$-terhiophene, ${ }^{13}$ Hex$\mathrm{Th}_{3} \mathrm{H}(2.10 \mathrm{~g}, 5.10 \mathrm{mmol})$, and $\mathrm{H}-\mathrm{C} \equiv \mathrm{C}-\mathrm{SiMe}_{3}(0.75 \mathrm{~g}, 7.65$ mmol) by Sonogashira coupling in the presence of tetrakis(triphenylphosphine)palladium, $\mathrm{Pd}\left(\mathrm{PPh}_{3}\right)_{4}$, and $\mathrm{CuI}$ at $65^{\circ} \mathrm{C}$ gave a yellow powder of $\mathrm{Hex}-\mathrm{Th}_{3}-\mathrm{C} \equiv \mathrm{C}-\mathrm{SiMe}_{3}(1.95 \mathrm{~g}, 4.56$ mmol, $90 \%$ yield). Treatment of the product with $\mathrm{KOH}$ gave a yellow powder of $\mathrm{Hex}-\mathrm{Th}_{3}-\mathrm{C} \equiv \mathrm{CH}$ in $92 \%$ yield. Reaction of the product with $\mathrm{N}$-chlorosuccinimide gave a yellow powder of Hex- $\mathrm{Th}_{3}-\mathrm{C} \equiv \mathrm{C}-\mathrm{Cl}$ in $58 \%$ yield. ${ }^{1} \mathrm{H}$ NMR $\left(\mathrm{CDCl}_{3}\right): \delta 7.10(\mathrm{~d}$, $3.9 \mathrm{~Hz}, 1 \mathrm{H}), 7.03(\mathrm{~d}, 3.9 \mathrm{~Hz}, 1 \mathrm{H}), 6.96(\mathrm{dd}, 3.9$ and $2.2 \mathrm{~Hz}, 3 \mathrm{H})$, $6.67(\mathrm{~d}, 3.9 \mathrm{~Hz}, 1 \mathrm{H}), 2.78(\mathrm{t}, 7.6 \mathrm{~Hz}, 2 \mathrm{H}), 1.65(\mathrm{t}, 7.6 \mathrm{~Hz}, 2 \mathrm{H})$, $1.31-1.23(\mathrm{~m}, 6 \mathrm{H}), 0.88(\mathrm{t}, 6.8 \mathrm{~Hz}, 3 \mathrm{H})$. Anal: Calcd. for $\mathrm{C}_{20} \mathrm{H}_{19} \mathrm{ClS}_{3}$ : C, 61.43\%; H, 4.90\%; Cl, 9.07\%; S, 24.60\%; Found: C, $61.43 \%$; H, $4.97 \%$; Cl, 8.96\%; S, 24.82\%.

The product $(0.66 \mathrm{~g}, 1.69 \mathrm{mmol})$ was added to the reaction mixture obtained by reaction of pyrrole $(0.13 \mathrm{~g}, 1.86 \mathrm{mmol})$ and sodium hydride $(45 \mathrm{mg}, 1.86 \mathrm{mmol})$ in THF $(30 \mathrm{~mL})$, and the mixture was stirred for $24 \mathrm{~h}$ at $60^{\circ} \mathrm{C}$. The obtained product was worked-up to obtain a pyrrole derivative having a Hex$\mathrm{Th}_{3}-\mathrm{C} \equiv \mathrm{C}$ - substituent at the $N$-position. The product $(0.24 \mathrm{~g}$, $0.57 \mathrm{mmol})$ was treated with NBS $(0.21 \mathrm{~g}, 1.20 \mathrm{mmol})$ in DMF $(30 \mathrm{~mL})$ at room temperature for $16 \mathrm{~h}$. After addition of water, the product was extracted with chloroform and worked-up by column chromatography on $\mathrm{SiO}_{2}$ (eluent $=$ hexane) to obtain an orange powder of monomer $2(0.32 \mathrm{~g}, 0.55 \mathrm{mmol}, 82 \%$ yield). Details of the synthesis of $\mathbf{2}$ and $\mathbf{P 3}$ will be reported elsewhere. ${ }^{1} \mathrm{H}$ NMR $\left(\mathrm{CDCl}_{3}\right): \delta 6.93(\mathrm{~d}, 3.9 \mathrm{~Hz}, 2 \mathrm{H}), 6.72(\mathrm{~d}$, $3.9 \mathrm{~Hz}, 1 \mathrm{H}), 6.64(\mathrm{~m}, 3 \mathrm{H}), 6.24(\mathrm{~s}, 2 \mathrm{H}), 2.76(\mathrm{t}, 7.6 \mathrm{~Hz}, 2 \mathrm{H})$, $1.65(\mathrm{t}, 7.6 \mathrm{~Hz}, 2 \mathrm{H}), 1.36-1.21(\mathrm{~m}, 6 \mathrm{H}), 0.87(\mathrm{t}, 6.7 \mathrm{~Hz}, 3 \mathrm{H})$. Anal: Calcd. for $\mathrm{C}_{24} \mathrm{H}_{21} \mathrm{Br}_{2} \mathrm{NS}_{3}$ : C, 49.75\%; $\mathrm{H}, 3.65 \% ; \mathrm{Br}$, $27.58 \%$; N, 2.42; S, 16.60\%; Found: C, 49.42\%; H, 3.50\%; Br, $27.36 \%$; N, 2.65\%; S, $16.31 \%$.

Preparation of P1-P3 was carried out as described below.

A mixture of the monomer $1 \mathrm{a}(0.91 \mathrm{~g}, 2.80 \mathrm{mmol}), \mathrm{Me}_{3} \mathrm{Sn}-$ $\mathrm{Th}_{2}-\mathrm{SnMe}_{3}(1.38 \mathrm{~g}, 2.80 \mathrm{mmol})$, and $\mathrm{Pd}\left(\mathrm{PPh}_{3}\right)_{4} \quad(0.162 \mathrm{~g}$, $0.14 \mathrm{mmol}$ ) in $30 \mathrm{~mL}$ of dry DMF was stirred for $48 \mathrm{~h}$ at $70^{\circ} \mathrm{C}$. The reaction mixture was poured into an aqueous solution of potassium fluoride and the mixture was stirred for $24 \mathrm{~h}$ at room temperature. The precipitate was collected by filtration, washed with diluted hydrochloric acid, aqueous ammonia, water, and methanol, and dried under vacuum to obtain a brown solid of P1 $(0.62 \mathrm{~g}, 1.88 \mathrm{mmol}$ based on the repeating unit, $67 \%$ yield). ${ }^{1} \mathrm{H}$ NMR $\left(\mathrm{DMF}_{-} d_{6}\right): \delta 7.72(2 \mathrm{H})$, $7.59(3 \mathrm{H}), 7.57(2 \mathrm{H}), 7.42(2 \mathrm{H}), 6.83(2 \mathrm{H})$. CP/MAS solid${ }^{13} \mathrm{C}$ NMR (100 MHz): d: 131.9, 127.8, 123.4, 112.5, 85.32, 72.87. Anal: Calcd. for $\left(\mathrm{C}_{20} \mathrm{H}_{11} \mathrm{NS}_{2}\right)_{\mathrm{n}}$ : C, $72.92 \%$; $\mathrm{H}, 3.37 \%$; N, 4.25; S, 19.47\%; Found: C, 70.44\%; H, 3.55\%; N, 3.70\%; S, $18.93 \%$. The discrepancy between the calculated and found values is considered to be, at least partly, due to high thermal stability of the polymer.

P2 was prepared analogously using the monomer $\mathbf{1 b}(0.36 \mathrm{~g}$, $1.06 \mathrm{mmol})$ and $\mathrm{Me}_{3} \mathrm{Sn}-\mathrm{Th}_{2}-\mathrm{SnMe}_{3}(0.52 \mathrm{~g}, 1.06 \mathrm{mmol})$, and P3 was prepared from the monomer $2(0.31 \mathrm{~g}, 0.54 \mathrm{mmol})$ and $\mathrm{Me}_{3} \mathrm{Sn}-\mathrm{Th}-\mathrm{SnMe}_{3}(0.22 \mathrm{~g}, 0.54 \mathrm{mmol})$. They were obtained in $35 \%$ and $46 \%$ yields. The low yields of $\mathbf{P 2}$ and $\mathbf{P 3}$ are considered to be due to loss of the polymer during work-up including repeated washing the polymers. ${ }^{1} \mathrm{H}$ NMR spectrum of $\mathbf{P 2}$ is shown in Figure 1, and $\mathrm{CP} / \mathrm{MAS}$ solid- ${ }^{13} \mathrm{C}$ NMR 
(100 MHz) showed peaks at $d=135.7,132.5,129.0,125.0$, 111.6, 81.2, 76.1, and 21.2. $\mathbf{P 3}$ gave the following ${ }^{1} \mathrm{H}$ NMR data in $\mathrm{CDCl}_{3}: \delta 7.50-6.20(\mathrm{br}, 8 \mathrm{H}$, Th-H), $6.13(2 \mathrm{H}$, pyrrole$\mathrm{H}), 2.70(2 \mathrm{H}), 1.63(2 \mathrm{H}), 1.25(6 \mathrm{H}), 0.81(3 \mathrm{H})$.

Acknowledgment. We are grateful to Professor T. Koizumi and Mr. Y. Yamagata of Tokyo Institute of Technology and Professor T. Shiono of Hiroshima University for helpful discussion and experimental supports. This work was partly supported by a Grant-in-Aid for Science Research in Priority Area "Super-Hierarchical Structures" from Ministry of Education, Culture, Sports, Science, and Technology, Japan.

Received: January 4, 2008 Accepted: April 16, 2008 Published: June 11, 2008

\section{REFERENCES}

1. a) T. A. Skotheim and J. R. Reynolds, "Handbook of Conducting Polymers," 3rd ed., Boca Raton, Florida, 2007.

b) D. Fichou, "Handbook of Oligo- and Polythiophenes," WileyVCH, Weinheim, 1999.

c) H. S. Nalwa, "Handbook of Organic Conductive Molecules and Polymers," Wiley, Chichester, 1997.

d) T. Yamamoto and H. Kokubo, Electrochim. Acta, 50, 1453 (2005).

2. a) F. Jonas and G. Heywang, Electrochim. Acta, 39, 1345 (1994). b) H. Tomozawa, Y. Saida, Y. Ikenoue, F. Murai, Y. Suzuki, T. Tawa, and Y. Ohta, J. Photopolym. Sci. Technol., 4, 707 (1996).

c) F. Wudl, M. Kobayashi, and A. J. Heeger, J. Org. Chem., 49, 3382 (1984).

3. Y. Kudoh, K. Akami, and M. Yasue, Synth. Met., 102, 973 (1999).
4. a) H. Röckel, J. Huber, R. Gleiter, and W. Schuhmann, Adv. Matrer., 6, 568 (1994).

b) W. Czerwinski, G. Wrzeszcz, K. Kania, J. F. Rabek, and L. A. Linden, J. Mater. Sci., 35, 2305 (2000).

c) G. Zotti, S. Zecchin, G. Schiavon, A. Berlin, G. Pagani, M. Borgonovo, and R. Lazzaroni, Chem. Mater., 9, 2876 (1997).

5. a) T. Yamamoto, M. Yoshizawa, A. Mahmut, M. Abe, S.-I. Kuroda, and S. Sasaki, J. Polym. Sci., Part A: Polym. Chem., 43, 6223 (2005). b) R. Yamashita, T. Koizumi, S. Sasaki, and T. Yamamoto, Polym. J., 39, 1202 (2007).

6. W. A. Little, Phys. Rev., 135, 1416 (1964).

7. a) H. A. Potts and G. F. Smith, J. Chem. Soc., 4018 (1957).

b) B. Sakurai, Bull. Chem. Soc. Jpn., 11, 374 (1936).

c) A. Sonn, Chem. Ber., 72B, 2150 (1039).

d) T. Yamamoto, Z.-H. Zhou, I. Ando, and M. Kikuchi, Makromol. Chem., Rapid Commun., 14, 833 (1993).

8. a) Y. Li, G. Vamvounis, and S. Holdcroft, Macromolecules, 35, 6900 (2002).

b) H. Hayashi and T. Yamamoto, Kobunshi Ronbunshu, 58, 221 (2001).

c) T. Sato, Z. Cai, T. Shiono, and T. Yamamoto, Polymer, 47, 37 (2006).

9. T. Yamamoto, D. Komarudin, M. Arai, B.-L. Lee, H. Suganuma, N Asakawa, Y. Inoue, K. Kubota, S. Sasaki, T. Fukuda, and H. Matsuda, J. Am. Chem. Soc., 120, 2047 (1998).

10. a) E. F. Jordan, Jr., D. W. Feldeisen, and A. N. Wrigley, J. Polym. Sci. Part A-1, 9, 1835 (1971).

b) H. W. Hsieh, B. Post, and H. Morawetz, J. Polym. Sci., Polym. Phys. Ed., 14, 1241 (1976).

11. a) V. N. Kuznetsov and N. Serpone, J. Phys. Chem. C, 111, 15277 (2007).

b) P. Kubelka and F. Munk, Z. Tech. Phys., 12, 593 (1931).

12. W. Verboom, H. Westmijze, L. De Noten, P. Vermeer, and H. J. T. Bos, Synthesis, 296 (1979).

13. A. Cravino, S. Roquet, O. Aleveque, P. Leriche, P. Frere, and J. Roncali, Chem. Mater., 18, 2584 (2006). 